\title{
Pemetaan potensi usaha desa dan penerapan "adwords" sebagai solusi menghadapi persaingan usaha pada BUMDes Bhuana Amertha Sari Desa Tampaksiring, Gianyar.
}

\author{
I Komang Sumerta ${ }^{1, *}$, Anak Agung Gede Rai ${ }^{2}$ \\ ${ }^{1}$ Fakultas Ekonomi dan Bisnis Universitas Ngurah Rai, Denpasar, Indonesia \\ ${ }^{2}$ Magister Administrasi Publik Universitas Ngurah Rai, Denpasar, Indonesia \\ *) Korespondensi (e-mail: komang.sumerta@unr.ac.id)
}

Received: 10-December-21; Revised: 15- December -21; Accepted: 16- December -21

\begin{abstract}
Bali has a lot of potential for strong local wisdom and culture as a provision in creating an alternative economy so that it relies not only on one tourism sector. One alternative is to develop Village Owned Enterprises (BUMDes). Based on the results of observations with the BUMDes administrator Bhuana Amerta Sari, Tampaksiring Village, Gianyar Regency, it was found that the business development managed by BUMDes Bhuana Amerta Sari, Tampaksiring Village, Gianyar Regency is still not optimal. In addition, management is still conventional, and product marketing is not optimal and has not implemented digital-based marketing in the face of increasingly fierce business competition. To overcome these problems, activities are designed that can answer the problems of partners, namely Bimtek and FGD of village potential in business development in the face of business competition. The results are various village business potentials that BUMDes can develop, mapping of village potential using SWOT analysis to measure the scale of business priorities.
\end{abstract}

Keywords: BUMDes, Village Potential Mapping, Business Competition, Digital Marketing.

\begin{abstract}
Abstrak
Bali memiliki banyak potensi kearifan lokal dan budaya yang kuat sebagai bekal dalam menciptakan alternative perekonomian sehingga tidak hanya bergantung pada satu sektor yaitu pariwisata saja. Salah satu alternative adalah dengan mengembangkan Badan Usaha Milik Desa (BUMDes). Berdasarkan hasil observasi dengan pengurus BUMDes Bhuana Amerta Sari Desa Tampaksiring Kabupaten Gianyar ditemukan bahwa masih belum optimalnya pengembangan usaha yang dikelola oleh BUMDes Bhuana Amerta Sari Desa Tampaksiring Kabupaten Gianyar. Selain itu pengelolaan manajemen yang masih konvensional serta pemasaran produk belum optimal dan belum mengadopsi pemasaran berbasis digital dalam menghadapi persaingan usaha yang semakin ketat. Untuk mengatasi permasalahan tersebut dirancang kegiatan yang dapat menjawab permasalahan mitra yaitu Bimtek dan FGD pemetaan potensi desa dalam pengembangan usaha dalam menghadapi persaingan usaha. Hasil kegiatan ini ditemukan berbagai potensi usaha desa yang dapat dikembangkan oleh BUMDes, pemetaan potensi desa menggunakan analisis SWOT untuk mengukur skala prioritas usaha.

Kata Kunci: BUMDes, Pemetaan potensi desa, persaingan usaha, Pemasaran digital.

How to cite: Sumerta, I. K., \& Rai, A. A. G. . (2021). Pemetaan potensi usaha desa dan penerapan "Adwords" sebagai solusi menghadapi persaingan usaha pada BUMDes Bhuana Amertha Sari Desa Tampaksiring, Gianyar. Penamas: Journal of Community Service, 1(2), 77-89. https://doi.org/10.53088/penamas.v1i2.225
\end{abstract}




\section{Pendahuluan}

Masa pandemi Covid-19 saat ini Bali mengalami dampak terburuk dari sisi ekonomi dimana perekonomian Bali sebagian besar bergantung pada sektor parisiwata. Pembatasan perjalanan serta kegiatan masyarakat memaksa Bali untuk menutup diri dari wisatawan baik nasional maupun internasional, meskipun saat ini wisatawan domestik sudah mulai diijinkan kembali dengan menerapkan protokol kesehatan yang sangat ketat. Berdasarkan data yang publikasikan oleh Badan Pusat Statistik (2020) menunjukkan bahwa pandemi covid ini memberikan dampak negative yang sangat besar pada sektor pariwisata Bali, hal ini ditunjukkan dengan menurunya jumlah wisatawan domestik dan mancanegara. Pertumbuhan Ekonomi Bali mengalami penurunan terendah di Indonesia yaitu sebesar $-9,31 \%$ jauh dibawah rata-rata pertumbuhan Ekonomi Nasional Tahun 2020 sebesar -2,07\%. Penurunan perekonomian Bali yang begitu signifikan dan terburuk se-Indonesia mengindikasikan bahwa industry pariwisata sangat rentan apabila dijadikan penopang utama perekonomian Bali, sehingga diperlukan alternative guna pembangunan perekonomian Bali kedepannya (Santosa \& Saraswati, 2020). Bali memiliki banyak potensi kearifan lokal dan budaya yang kuat sebagai bekal dalam menciptakan alternative perekonomian sehingga tidak hanya bergantung pada satu sektor yaitu pariwisata saja. Salah satu alternative adalah dengan mengembangkan Badan Usaha Milik Desa (BUMDes).

Menurut (Mutiarni et al., 2018) Program pemberdayaan ekonomi dan peningkatan jaminan sosial masyarakat desa sudah sejak lama dijalankan oleh Pemerintah melalui berbagai program. Namun upaya itu belum membuahkan hasil yang memuaskan sebagaimana diinginkan bersama. Banyak faktor yang mempengaruhi keberhasilan program - program ini dimasyarakat, beberapa hal diantaranya adalah:

1. Program pemberdayaan ekonomi yang masih bersifat parsial dan sectoral

2. Mensyaratkan pembentukan lembaga (unit pelaksana), yang tidak jarang tugas dan fungsinya tidak jauh berbeda dengan lembaga yang dibentuk pada program lain.

3. Berusia pendek dan belum bersifat bekelanjutan, jika program berakhir maka berakhir juga kerja lembaga tersebut. Permasalahan ego-sektoral dari lembagalembaga tersebut tidak jarang menjadi permasalahan baru di desa. Daripada bertujuan untuk meningkatkan kemandirian ekonomi masyarakat, tidak jarang lembaga ekonomi tersebut harus tumpeng tindih dengan lembaga ekonomi yang lainnya.

Belajar dari kurang efektifnya pelaksanaan program yang sudah ada, satu pendekatan baru yang diharapkan mampu menstimuli dan menggerakkan roda pereknomian di pedesaan adalah melalui penyatuan pengelolaan kelembagaan ekonomi yang ada asset ekonomi yang ada di desa harus dikelola sepenuhnya oleh masyarakat desa. Bentuk kelembagaan sebagaimana disebutkan di atas dinamakan Badan Usaha Milik Desa (BUMDes). Badan usaha ini sesungguhnya telah diamanatkan di dalam UU no. 32 tahun 2004 tentang pemerintah daerah. Dalam UU 
tersebut pada pasal 213 ayat (1) disebutkan bahwa "Desa dapat mendirikan badan usaha milik desa sesuai dengan kebutuhan dan potensi desa", selain itu tujuan pendirian BUMDes antara lain dalam rangka peningkatan Pendapatan Asli Desa (PADes). (Nurwahidah et al., 2020; Senjani, 2019; Srirejeki et al., 2020)

\section{Analisis Situasi}

Salah satu BUMDes yang sudah mulai berkembang di Bali adalah BUMDes Bhuana Amertha Sari Desa Tampaksiring Kabupaten Gianyar. BUMDes merupakan salah satu sumber pendapatan dan sumber pengembangan usaha masyarakat di Desa Tampaksiring. BUMDes ini memiliki peran dalam menciptakan lapangan kerja bagi masyarakat setempat. Berdasarkan hasil observasi dengan pengurus BUMDes Bhuana Amerta Sari Desa Tampaksiring Kabupaten Gianyar ditemukan bahwa masih belum optimalnya pengembangan usaha yang dikelola oleh BUMDes Bhuana Amerta Sari Desa Tampaksiring Kabupaten Gianyar. Saat ini BUMDes yang baru berdiri sejak tahun 2018 lalu ini hanya mengelola Simpan Pinjam, Toko Sembako, Pasar Desa dan Desa Wisata.

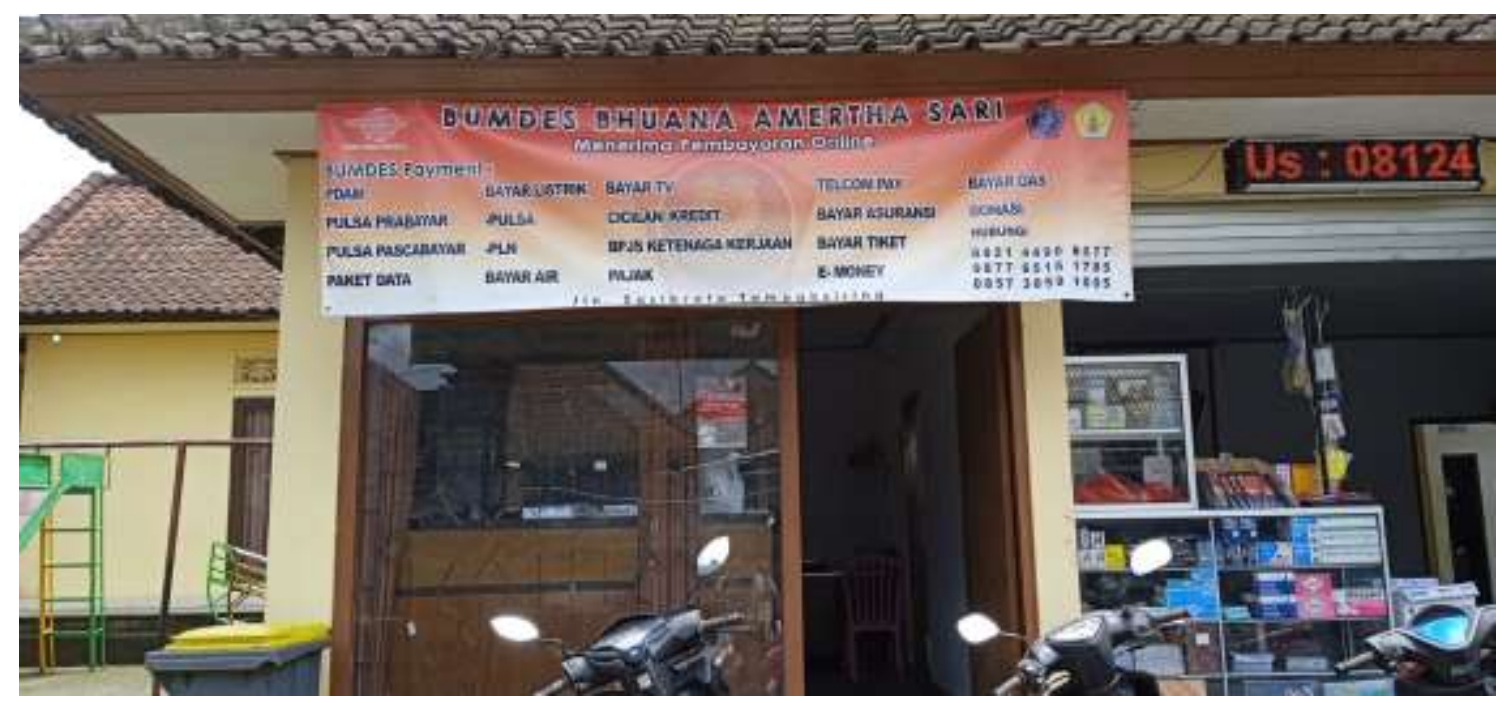

Gambar 1. Kantor BUMDes Bhuana Amerta Sari

BUMDes Bhuana Amertha Sari memiliki kantor yang berlokasi tepat disebelah dari kantor Perbekel Desa Tampaksiring. Melalui kantor ini seluruh proses manajemen dan proses bisnis dalam menjalankan unit-unit usaha yang dikelola oleh BUMDes ini dijalankan khususnya usaha simpan pinjam yang dikelola oleh BUMDes Bhuana Amerta Sari ini. Saat ini sarana dan prasarana kantor masih sangat minim dan cukup sederhana, sebagian besar pencatatan dan pembukuan dilakukan secara manual dan hanya tersedia 2-unit komputer untuk melayani seluruh transaksi dan keperluan administrasi.

Selain difungsikan sebagai kantor, bagunan yang merupakan asset desa itu juga difungsikan sebagai toko sembako yang menjual kebutuhan pokok masyarakat desa setempat, namun penataan produk yang jual masih tidak tersusun dengan baik, sehingga menyulitkan pembeli untuk mencari kebutuhan yang ingin mereka beli. 

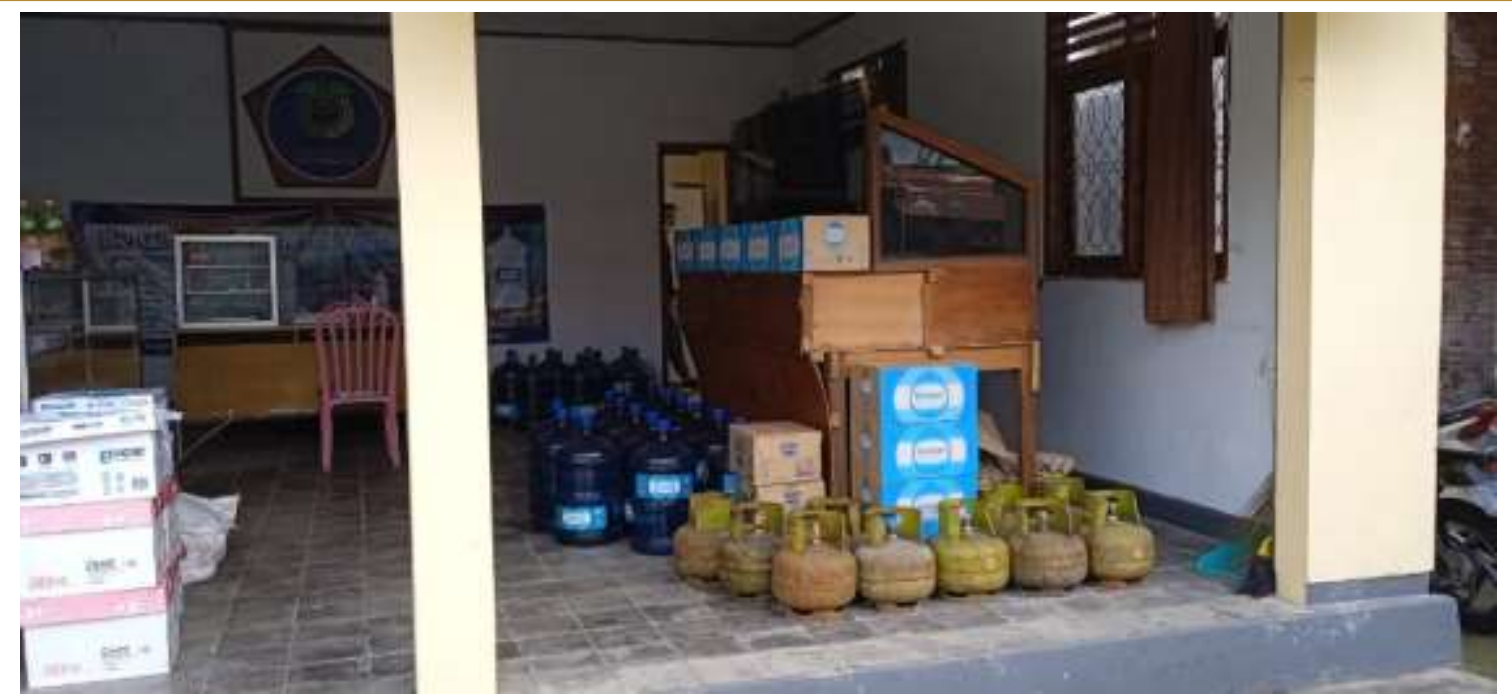

Gambar 2. Toko Sembako yang dikelola oleh BUMDes Bhuana Amertha Sari

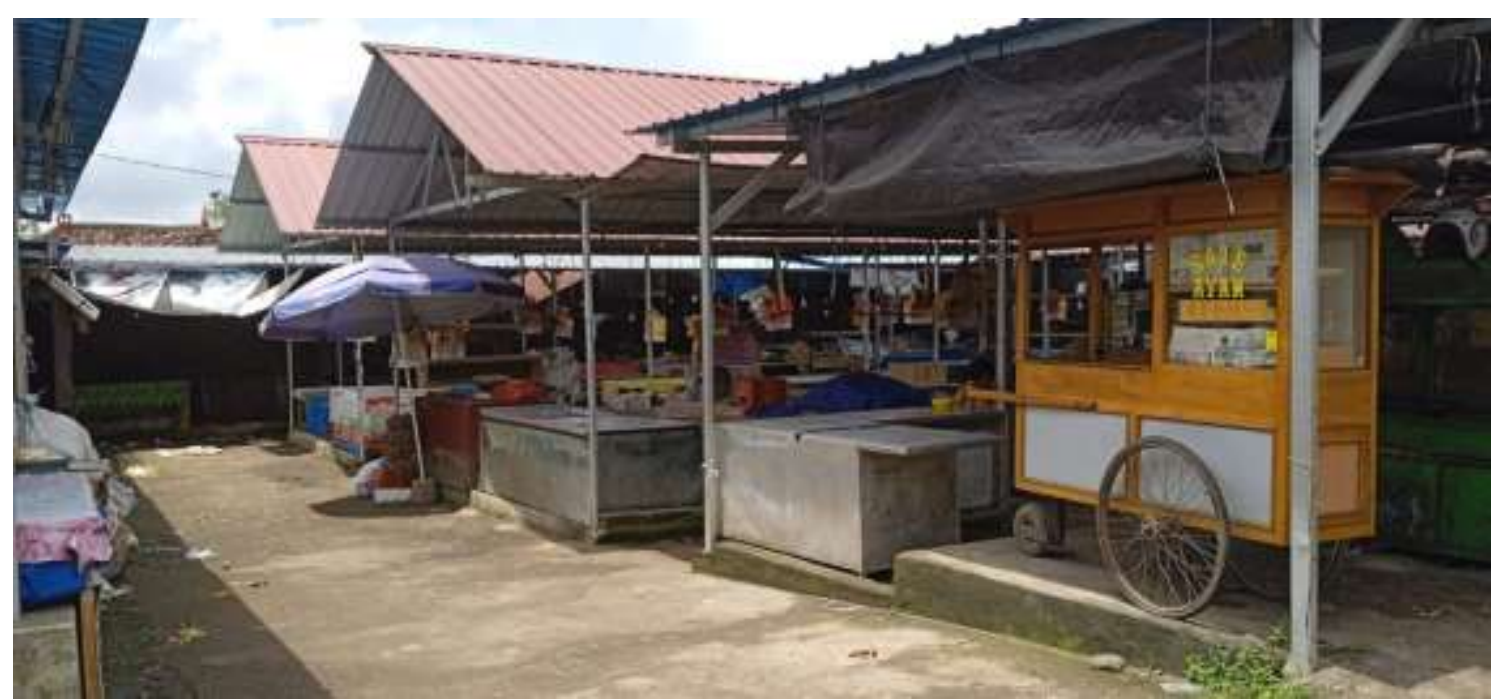

Gambar 3. Pasar Desa yang dikelola oleh BUMDes Bhuana Amerta Sari

Pengembangan usaha yang dikelola BUMDes Bhuana Amerta Sari Desa Tampaksiring mengalami kendala khususnya dibidang sumber daya manusia dan manajemen dalam mengelolan dan pengembangan usaha. Pengembangan usaha sangat penting dilakukan untuk kemajuan usaha yang bekelanjutan (Mutiarni et al., 2018; Senjani, 2019; Situmorang, 2020) untuk itu BUMDes Bhuana Amerta Sari perlu melakukan pemetaan dan pengembangan usaha sehingga dapat memperluas pangsa pasar yang dituju (Srirejeki et al., 2020). Dengan melakukan pengembangan usaha tentunya dirahapkan pula akan meningkatkan penghasilan desa melalui PADes, selain itu akan membuka peluang peningkatan lapangan kerja bagi warga setempat sehingga muaranya adalah peningkatan kesejahteraan warga desa. Pengembangan usaha BUMDes dapat dilakukan melalui penggalian potensi usaha, pengembangan dan pendampingan usaha yang sudah ada serta pembenahan sistem manajemen dan tata kelola pada BUMDes dalam peningkatan produktifitas dan kinerja baik dari sisi kemampuan sumber daya maupun dari sisi omset yang ingin dicapai. Sistem 
pengelolaan manajemen serta pemasaran produk yang masih konvensional menjadi kendala yang dihadapi mitra dalam memasarkan produknya.

Perkembangan teknologi yang semakin pesat, menuntut semua sektor usaha termasuk BUMDes untuk dapat beradaptasi dalam perkembangan teknologi tersebut. Minat wirausaha yang minim dikalangan masyarakat (Sumerta et al., 2020), menuntut adanya inovasi dalam pengembangan usaha khususnya usaha yang berbasis desa.Saat ini BUMDes Bhuana Amertha Sari masih menggunakan pemasaran secara konvensional dengan menawarkan produk kepada warga desa, tentu saja dengan sistem yang masih konvensional ini tidak akan mampu bersaing dengan usaha-usaha sejenis lainnya yang sudah menggunakan fasilitas pemasaran produk berbasis digital.

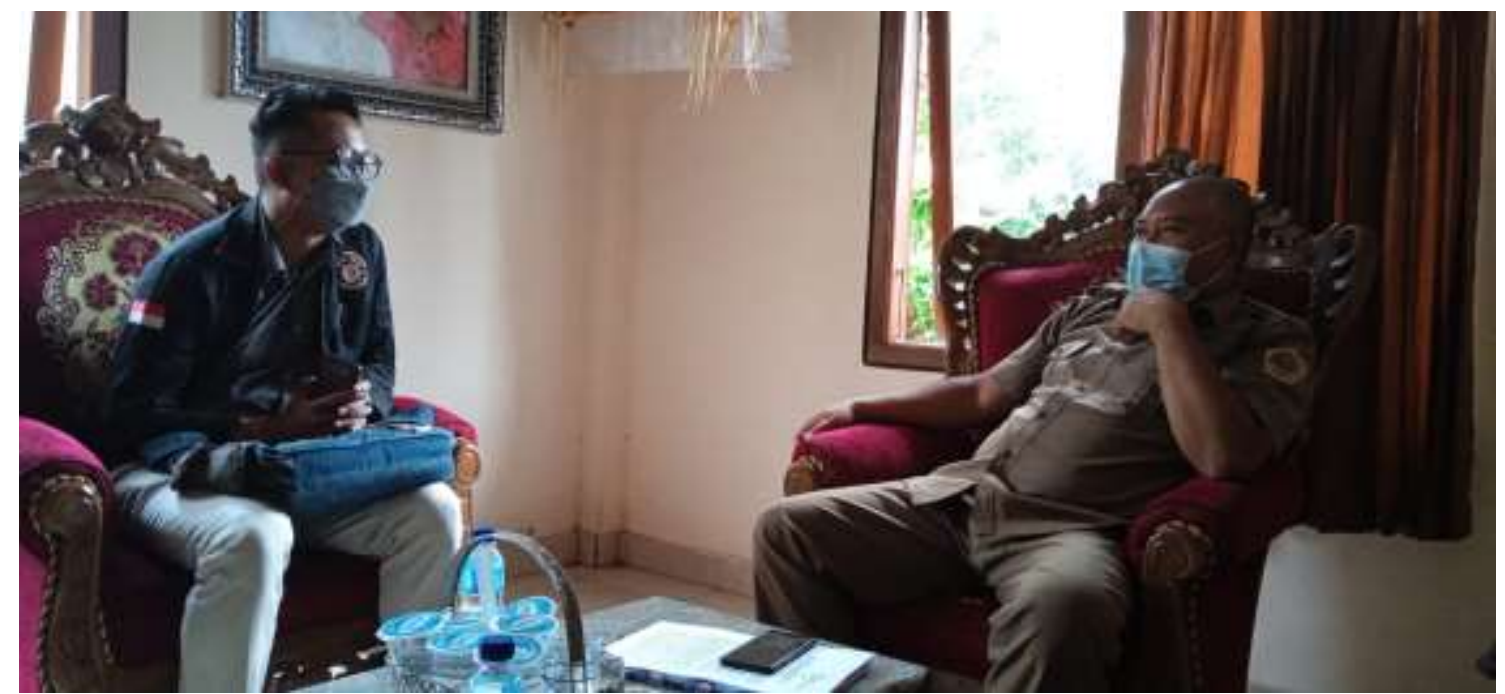

Gambar 4. Kegiatan Observasi Lapangan dengan Perbekel Desa Tampaksiring

Perilaku konsumen saat ini sudah mengarah kepada produk-produk yang berbasis digital, sehingga pemasar harus menerapkan pemasaran secara online atau digital marketing (Sumerta et al., 2019). Digital marketing adalah suatu kegiatan pemasaran atau promosi sebuah brand atau produk menggunakan media digital atau internet. Tujuan digital marketing adalah untuk menarik konsumen dan calon konsumen secara cepat. Seperti yang kita tahu, penerimaan teknologi dan internet di masyarakat sangat luas sehingga tidak heran kegiatan pemasaran secara digital dijadikan pilihan utama oleh perusahaan-perusahaan (Junusi, 2020). Digital marketing adalah kegiatan pemasaran termasuk branding yang menggunakan berbagai media. Sebagai contoh yaitu blog, website, e-mail, adwords, dan berbagai macam jaringan media sosial (Busca \& Bertrandias, 2020; Diez-Martin et al., 2019). Salah satu pemasaran digital yang mudah di implementasikan untuk usaha mikro kecil dan menengah adalah menggunakan adsword. Google AdWords adalah sebuah strategi pemasaran periklanan baru yang menggunakan mesin pencarian Google sebagai saran beriklan, biasa disebut juga sebagai Search Engine Marketing atau pemasaran berbasis mesin pencari. 


\section{Permasalahan Mitra}

Mengacu kepada butir analisis situasi, permasalahan prioritas mitra mencakup hal-hal sebagai berikut:

a. Permasalahan pengembangan bisnis yang dijalankan oleh BUMDes. Saat ini usaha BUMDes perlu memikirkan pengembangan bisnis yang bisa dilakukan sehingga memperluas penetrasi pasar dan penetrasi usaha yang dijalankan yang diharapkan akan linier dengan meningkatnya PADes. Salah satu langkah awal yang dapat dilakukan adalah dengan melakukan pemetaan potensi usaha desa yang dapat dikelola dan dikembangkan oleh BUMDes.

b. Sistem manajemen dan pengelolaan usaha yang masih konvensional serta pembukuan dan pencatatan transaksi yang masih manual sehingga menyulitkan pengelola dalam menilai hasil transaksi dan dalam penyusunan laporan. Hal tersebut memberikan dampak kurang tepatnya stakelholder dalam pengambilan keputusan maupun kebijakan dikarenakan laporan yang tidak akurat.

c. Sistem pemasaran produk yang masih konvesional dan belum menggunakan fasilitas pemasaran berbasis digital. Hal tersebut mengakibatkan keterbatasan ruang gerak pengurus BUMDes dalam memasarkan dan memperkenalkan produk yang dimiliki kepada masyarakat Desa khususnya dan masyarakat luas pada umumnya.

\section{Solusi dan Target}

Sesuai dengan permasalahan yang dihadapi oleh pengelola dan pengurus BUMDes Bhuana Amertha Sari dalam menghadapi persaingan usaha yang semakin ketat maka diperlukan langkah-langkah yang dijadikan solusi yaitu:

a) Permasalahan pengembangan bisnis yang dijalankan oleh BUMDes. Saat ini usaha BUMDes perlu memikirkan pengembangan bisnis yang bisa dilakukan sehingga memperluas penetrasi pasar dan penetrasi usaha yang dijalankan yang diharapkan akan linier dengan meningkatnya PADes. Salah satu langkah awal yang dapat dilakukan adalah dengan melakukan pemetaan potensi usaha desa yang dapat dikelola dan dikembangkan oleh BUMDes. Pemataan potensi desa ini dilaksanakan dengan cara Focus Group Discusion dan Workshop yang berfokus membahas terkait dengan pemetaan usaha yang potensial dikembangkan di desa tesebut. Workshop ini akan melibatkan seluruh anggota BUMDes dan juga perwakilan dari perangkat desa serta mengampu kebijakan dilingkungan Desa. Narasumber dalam workshop ini adalah praktisi dan ahli dibidang pengembangan usaha, stragegi bisnis, dan administrasi public. Luaran yang diharapkan dari kegiatan ini adalah BUMDes memiliki pemetaan potensi usaha yang dimiliki oleh Desa, yang dapat dikembangkan kedepan dalam jangka pendek, mengengah maupun jangka Panjang.

b) Sistem manajemen dan pengelolaan usaha yang masih konvensional serta pembukuan dan pencatatan transaksi yang masih manual sehingga menyulitkan pengelola dalam menilai hasil transaksi dan dalam penyusunan laporan. Hal tersebut memberikan dampak kurang tepatnya stakelholder dalam pengambilan 
keputusan maupun kebijakan dikarenakan laporan yang tidak akurat. Permasalahan ini dapat diselesaikan dengan memberikan pendampingan pengelolaan management usaha yang terstruktur. Pendampingan dilakukan oleh dosen pendamping dan/atau ahli lainnya yang dibutuhkan oleh mitra. Pendampingan ini akan lebih intens dilaksanakan dengan pendekatan praktis dan langsung melakukan implementasi khususnya pada permasalahan yang dihadapi mitra. Pendapingan ini akan dialokasikan waktu selama 8 kali pertemuan sehingga dapat terlihat bagaimana progress dan efektifitas pendampingan yang diberikan. Luaran yang diharapkan dari kegiatan ini adalah tersedianya laporan keuangan yang representative dan mudah untuk diterjemahkan dalam pembuatan kebijakan oleh mitra.

c) Sistem pemasaran produk yang masih konvesional dan belum menggunakan fasilitas pemasaran berbasis digital. Hal tersebut mengakibatkan keterbatasan ruang gerak pengurus BUMDes dalam memasarkan dan memperkenalkan produk yang dimiliki kepada masyarakat Desa khususnya dan masyarakat luas pada umumnya. Permasalahan pemasaran produk usaha merupakan permasalahan bagi setiap pengusaha, namun dengan adanya perkembangan teknologi, pemasaran produk menjadi lebih mudah untuk dikembangkan. Permasalahan yang dihadapi oleh mitra terkait dengan pemasaran produk ini akan diberikan solusi dengan memberikan pendampingan dan pelatihan penggunaan adsword dan pemasaran digital. Pendampingan juga akan dilaksanakan selama 8 kali untuk melihat perkembangan dan efektifitas pemasaran yang berbasis digital ini diterapkan. Target luaran yang diharapkan dari kegiatan ini adalah meningkatnya omset BUMDes sebanyak 20\% dari sebelumnya

\section{Metode Pengabdian}

\section{Metode Pendekatan.}

Berdasarkan hasil identifikasi masalah yang dilakukan di lapangan, maka metode pendekatan yang dilakukan adalah :

1. Metode Edukasi bertujuan untuk memberikan pemahaman bahwa permasalahan yang dihadapi dan penyampaian solusi serta target capaian.

2. Metode Pelatihan yang ditujukan untuk memberikan keterampilan terhadap penyusunan laporan maupun penggunaan adsword serta pemasaran berbasis digital.

3. Metode Pendampingan yang dilakukan untuk meningkatkan pengetahuan dan memantapkan keterampilan mitra dalam mencapai tujuan atau target capaian program.

4. Metode Evaluasi program dengan tujuan untuk mengevaluasi berbagai tahapan kegiatan sehingga dapat mempebaiki dan menyempurnakan pelaksanaan kegiatan di lapangan

5. Metode Keberlanjutan program dengan tujuan memantau kegiatan di lapangan setelah kegiatan berakhir agar tetap dapat dilanjutkan oleh mitra. 


\section{Tahap Persiapan}

Tahapan ini meliputi studi pustaka, pengurusan ijin, observasi, penyampaian solusi terhadap mitra, kordinasi dan pembagian tugas tim pelaksana, penetapan lokasi kegiatan pelatihan, koordinasi jadwal kegiatan dengan mitra, penyiapan bahan dan alat yang diperlukan sesuai tahapan kegiatan di lapangan.

\section{Tahap Pelaksanaan Kegiatan}

Berdasarkan solusi yang telah disepakati , maka untuk mengatasi permasalahan yang telah ditetapkan bersama yaitu:

a) Bimbingan Teknis dan FGD pemetaan potensi desa dalam pengembangan usaha dalam menghadapi persaingan usaha, yang diselenggarakan di Desa lokasi mitra serta diikuti oleh seluruh stakeholder yang terkait seperti anggota BUMDes, apartur desa dan perwakilan warga.

b) Pendampingan dan pelatihan manajemen bisnis dan pembuatan laporan usaha kepada staff dan pegawai BUMDes, pendampingan ini bersifat personal dan terjadwal sehingga dapat dilihat perkembangan dari setiap tahapan pendampingan

c) Pendampingan dan pelatihan pemasaran digital dan penggunaan adsword kepada staff dan pegawai BUMDes, pendampingan ini juga bersifat personal dan terjadwal sehingga dapat diliahat perkembangan penjualan dari setiap tahapan pendampingan, dan dapat dipantau efektifitas penggunaan pemasarna digital bagi BUMDes.

\section{Hasil Pengabdian}

Desa yang mandiri merupakan desa yang mampu memiliki Pendapadan Asli Daerah (PAD) yang termasuk dalam APBDes desa tersebut. Salah satu pendapatan potensial yang dapat dimiliki oleh Desa yaitu melalui pengembangan Badan Usaha Milik Desa (BUMDes). BUMDes sebagai salah satu lembaga yang dibentuk desa untuk mengelola sumber daya yang ada di desa harus mampu mengoptimalkan segala potensi yang ada dan yang sudah berkembang untuk dikelola sehingga menjadi lebih besar dan menjadi sumber pendapatan desa tersebut.

Desa Tampaksiring melalui BUMDes Bhuana Amerta Sari sebagai lembaga pengelola sumber daya desa telah menjalankan berbagai bidang usaha untuk mengakomodir potensi - potensi tersebut. Namun Desa Tampaksiring memiliki potensi yang masih banyak yang masih harus digali dan dipetakan untuk program pengembangan jangka Panjang. Salah satu kegiatan pengambdian masyarakat yang dilakukan yaitu pemetaan potensi usaha desa tampaksiring yang dapat dikelola oleh BUMDes Bhuana Amerta Sari.

Pemetaan potensi usaha desa yang dapat dikelola oleh BUMDes Bhuana Amertha dilaksanakan dengan Bimbingan teknis yang dilanjutkan dengan Focus Group Discussion oleh seluruh stakeholder BUMDes, Pengurus Desa, perwakilan UMKM, Praktisi dan Akademisi. Dalam kegiatan Bimtek sebagai narasumber kegiatan 
menghadirkan Guru Besar IImu Manajemen khususnya bidang ilmu manajemen pemasaran dan manajemen strategi dari Universitas Udayana Bali sebagai narasumber utama yaitu Prof. Dr. Ni Nyoman Kerti Yasa, M.S. Potensi Usaha desa dapat dikembangkan melalui 4 tahapan yang sangat utama:

a. Desa harus dapat mengenal jenis - jenis usaha desa yang umum dikembangkan.

b. Mengenal potensi atau peluang usaha yang dapat dikembangkan.

c. Pemilihan dan penngambilan keputusan

d. Menentukan strategi pengembangan usaha desa.

Keempat langkah di atas harus dipetakan secara sistematis oleh seluruh stakeholder yang terlibat didalam pengembangan usaha yang dikelola oleh BUMDes khususnya di BUMDes Bhuana Amertha Sari Desa Tampaksiring Gianyar - Bali. Bimtek dan FGD yang dilakukan membahas secara mendalam jenis - jenis usaha apa saya yang ada dan mungkin dapat dikembangkan kembali sebagai usaha yang potensial yang dikelola oleh BUMDes. Jenis - jenis usaha dikelompokkan menjadi 4 kategori kelompok yaitu kelompok usaha dagang / toko, kelompok ternak, kelompok usaha jasa dan kelompok usaha pertanian. Pemetaan kelompok usaha ini akan memudahkan dalam melakukan identifikasi potensi usaha yang sudah ada dan/atau yang berpotensi untuk dilakukan pengembangan secara lebih berkelanjutan di BUMDes Bhuana Amerta Sari Desa Tampaksiring, Gianyar - Bali. Dalam Bimbingan teknis dan FGD yang dilakukan ditemukan pemetaan jenis - jenis usaha Desa Tampaksiring sebagai berikut yang tertuang dalam gambar 5 .

\section{Jenis-jenis Usaha Desa}

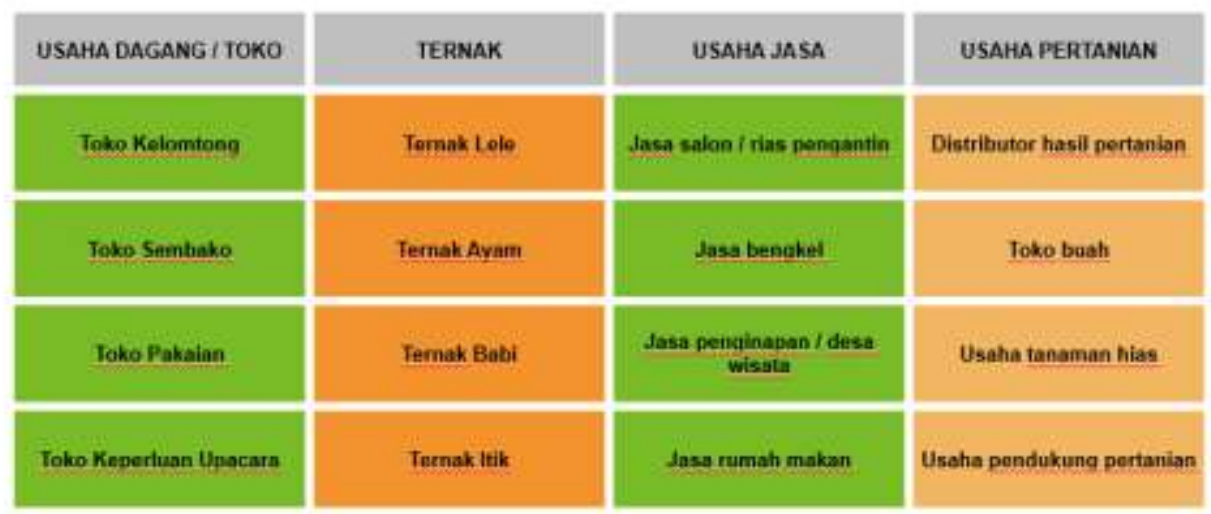

Gambar 5. Jenis Jenis Usaha Desa Tampaksiring

Berdasarkan hasil pemaparan oleh para ahli disampaikan bahwa proses identifikasi potensi usaha Desa Tampaksiring harus melalui 4 tahapan yaitu pertama desa harus melakukan identifikasi usaha yang sudah ada di Desa Tampaksiring itu sendiri misalnya Usaha Kerjaninan (kerajinan tulang), dalam bidang Desa Wista (Istana 
Tampaksiring dan Subak Pulagan), Bidang Koperasi (Koperasi simpan pinjam dan koperasi serba usaha). Langkah identifikasi kedua dilakukan dengan identifikasi usaha desa yang belum ada tapi yang potensial, misalnya adalah jasa rumah makan yang dikelola oleh BUMDes, Kelompok Pertanian dan Kelompok Peternakan. Langkah ketiga yaitu melakukan kajian kelayakan yang dilihat dari aspek pasar dan pemasaran. Langkah yang terakhir yaitu merumuskan strategi mencapai pasar yang menjadi sasaran.

Pemetaan potensi usaha desa dilakukan dengan Teknik analisis SWOT dimana desa melakukan pemetaan antara sumber daya dan peluang yang ada untuk menentukan skala prioritas usaha yang akan dijalankan. Dalam analisis tersebut sebagai prioritas utama atau pertama yaitu usaha yang memiliki sumber daya tinggi dan juga peluang tinggi, seperti usaha peternakan dan pertanian karena lokasi dan sumber daya sangat mendukung. Perioritas kedua yaitu memiliki peluang tinggi namun sumber daya rendah seperti distributor hasil pertanian, toko buah, usaha pendukung pertanian, jasa rumah makan, dan jasa penginapan desa wisata. Perioritas ketiga yaitu dengan peluang yang rendah namun memiliki sumber daya yang tinggi seperti toko pakaian, ternak itik. Sebagai prioritas keempat yaitu usaha yang memiliki peluang rendah dan juga sumber daya rendah seperti jasa bengkel sepeda motor.

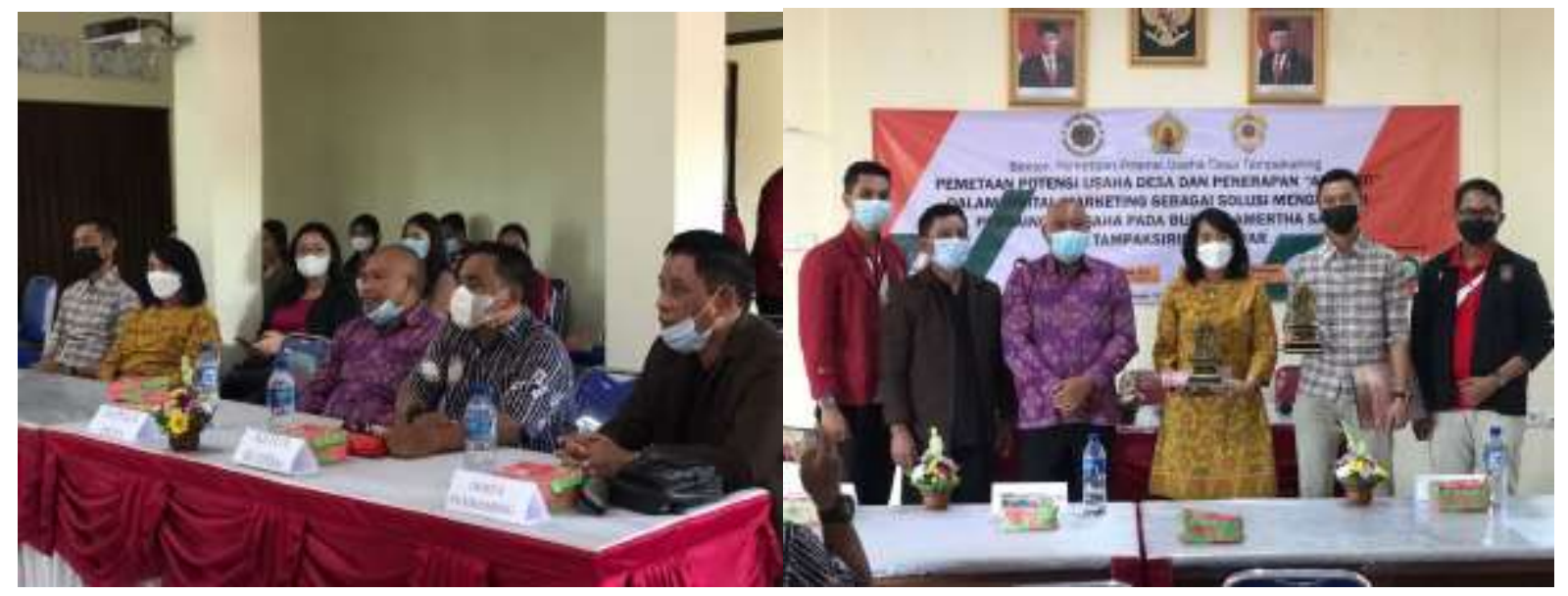

Gambar 6. Kegiatan Bimbingan Teknis Pemetaan Potensi Desa dan Pelatihan Marketing Digital berbasis Adwords

Kegiatan kedua yang dilakukan yaitu Pendampingan dan pelatihan manajemen bisnis dan pembuatan laporan usaha kepada staff dan pegawai BUMDes, pendampingan ini bersifat personal dan terjadwal sehingga dapat dilihat perkembangan dari setiap tahapan pendampingan. Pendampingan dilakukan setiap minggu selama 8 kali pertemuan yang dilakukan di kantor BUMDes Bhuana Amerta Sari Desa Tampaksiring Gianyar Bali. Pendampingan ini bertujuan untuk memberikan edukasi kepada staff BUMDes dalam penyusunan laporan keuangan maupun laporan - laporan lainnya yang berkaitan dengan pelaksanaan usaha, sehingga pihak pimpinan dan stakeholder lainnya yang terlibat dapat memperoleh informasi yang komprehensif yang membantu dalam pengambilan keputusan. 


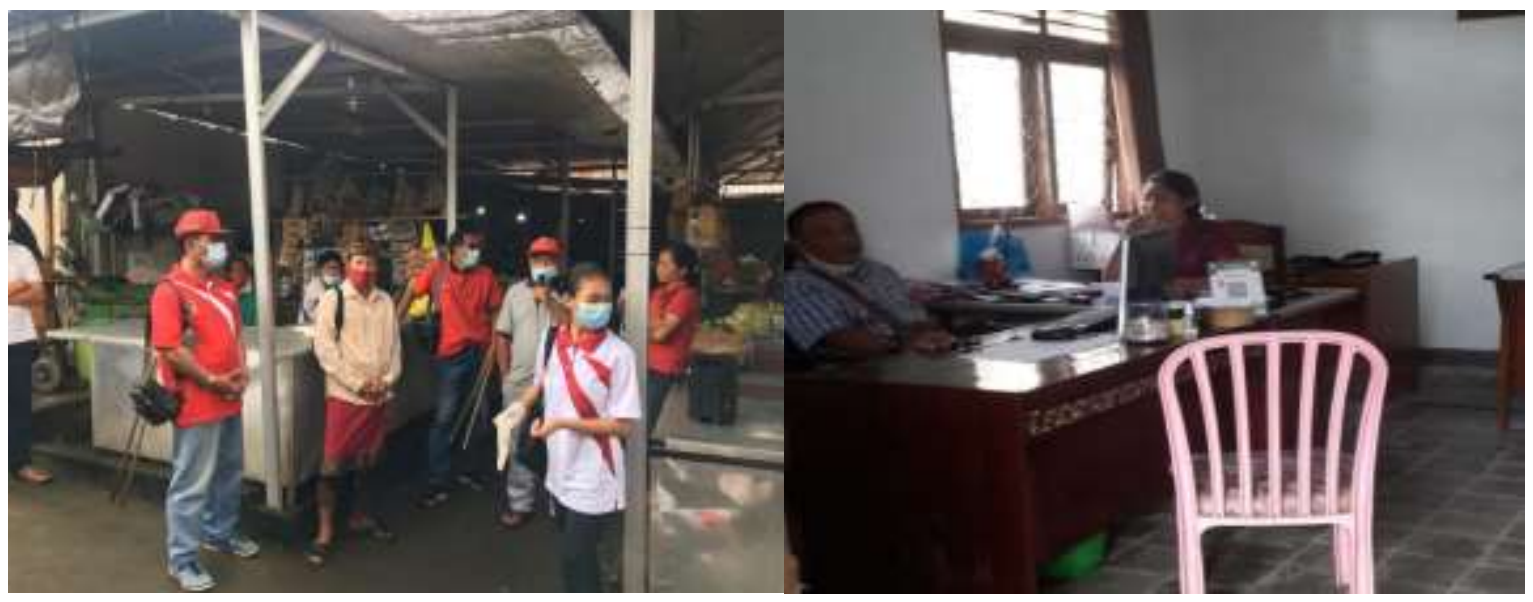

Gambar 7. Proses Pendampingan

Kegiatan ketiga yang dilakukan yaitu Pendampingan dan pelatihan pemasaran digital dan penggunaan adword kepada staff dan pegawai BUMDes, pendampingan ini juga bersifat personal dan terjadwal sehingga dapat diliahat perkembangan penjualan dari setiap tahapan pendampingan, dan dapat dipantau efektifitas penggunaan pemasarna digital bagi BUMDes. Pendampingan dilakukan setiap minggu selama 8 kali pertemuan yang dilakukan di kantor BUMDes Bhuana Amerta Sari Desa Tampaksiring Gianyar. Pendampingan ini bertujuan untuk memberikan edukasi teknis terkait pemasaran digital berbasis adword dalam memasarkan produk - produk yang dimiliki oleh BUMDes Desa Tampaksiring Gianyar.

\section{Kesimpulan}

Hasil pengabdian pemetaan potensi usaha desa dengan teknik analisis SWOT untuk menentukan skala prioritas usaha menunjukkan bahwa prioritas utama atau pertama yaitu usaha yang memiliki sumber daya tinggi dan juga peluang tinggi, seperti usaha peternakan dan pertanian karena lokasi dan sumber daya sangat mendukung. Perioritas kedua yaitu memiliki peluang tinggi namun sumber daya rendah seperti distributor hasil pertanian, toko buah, usaha pendukung pertanian, jasa rumah makan, dan jasa penginapan desa wisata. Perioritas ketiga yaitu dengan peluang yang rendah namun memiliki sumber daya yang tinggi seperti toko pakaian, ternak itik. Sebagai prioritas keempat yaitu usaha yang memiliki peluang rendah dan juga sumber daya rendah seperti jasa bengkel sepeda motor.

Pendampingan dan pelatihan manajemen bisnis dan pembuatan laporan usaha kepada staff dan pegawai BUMDes, dapat mengedukasi kepada staff BUMDes dalam penyusunan laporan keuangan maupun laporan - laporan lainnya yang berkaitan dengan pelaksanaan usaha. Sementara pedampingan dalam mendukung pemasaran digital berbasis adword, BUMDes dapat membentuk suatu wadah virtual / digital yang mampu mengakomodir semua produk dan usaha yang dijalankan dalam satu wadah virtual, serta mampu memberikan informasi yang terbaru kepada seluruh konsumen potensial, sehingga proses pemasaran secara digital dapat berjalan dengan efektif. 


\section{Ucapan Terimakasih}

Terimakasih kami ucapkan kepada seluruh pihak yang telah terlibat dalam menyukseskan kegiatan pengabdian masyarakat ini. Khususnya kami ucapkan terimakasih kepada pimpinan dan jajaran Desa Tampaksiring, Pimpinan dan jajaran BUMDes Bhuana Amerta Sari Desa Tampaksiring, Masyarakat Desa Tampaksiring yang telah menyediakan waktu dan tempat untuk kami dapat melakukan kegiatan dan program - program pengabdian. Terimakasih kami juga sampaikan kepada Yayasan Jagadhita Denpasar sebagai badan hukum penyelenggaran Universitas Ngurah Rai, kepada Rektor Universitas Ngurah Rai dan Lembaga Penelitian dan Pengabdian Kepada Masyarakat Universitas Ngurah Rai yang telah memberikan pendanaan penuh terhadap kegiatan ini. Terimakasih juga kami ucapkan kepada seluruh sponsor, pihak-pihak lain dan mahasiswa Universitas Ngurah Rai yang terlibat membantu menyukseskan kegiatan ini.

\section{Referensi}

Busca, L., \& Bertrandias, L. (2020). A Framework for Digital Marketing Research: Investigating the Four Cultural Eras of Digital Marketing. Journal of Interactive Marketing, 49. https://doi.org/10.1016/j.intmar.2019.08.002

Diez-Martin, F., Blanco-Gonzalez, A., \& Prado-Roman, C. (2019). Research challenges in digital marketing: Sustainability. Sustainability (Switzerland), 11(10). https://doi.org/10.3390/su11102839

Junusi, R. El. (2020). Digital Marketing During the Pandemic Period; A Study of Islamic Perspective. Journal of Digital Marketing and Halal Industry, 2(1). https://doi.org/10.21580/jdmhi.2020.2.1.5717

Mutiarni, R., Zuhroh, S., \& Utomo, L. P. (2018). Pendampingan Pencatatan Transaksi Dan Penyusunan Laporan KeuanganBadan Usaha Milik Desa (Bumdes) Putra Subagyo Desa Miagan - Jombang. Comvice : Journal of Community Service, 2(1). https://doi.org/10.26533/comvice.v2i1.124

Nurwahidah, S., Angkasa, M. A. Z., \& Kusuma, R. R. (2020). Formulasi Strategi Pengembangan Badan Usaha Milik Desa (Bumdes) (Studi Kasus di Kabupaten Sumbawa). PROSIDING SEMINAR NASIONAL IPPeMas, 1(1).

Santosa, A., \& Saraswati, L. A. N. (2020). Pariwisata Kerta Masa: Gagasan Alternatif Kebijakan Pembangunan Pariwisata Bali. ... (Udayana Master Law Journal), 9(4), 723-738. https://doi.org/https://doi.org/10.24843/JMHU.2020.v09.i04.p05

Senjani, Y. P. (2019). Peran Sistem Manajemen Pada Bumdes Dalam Peningkatan Pendapatan Asli Desa. Kumawula: Jurnal Pengabdian Kepada Masyarakat, 2(1). https://doi.org/10.24198/kumawula.v2i1.23698

Situmorang, D. M. (2020). Pelatihan Dan Penerapan Sistem Akuntansi Pada BUMDes Di Kabupaten Bengkayang. Cendekia: Jurnal Pengabdian Masyarakat, 2(1). https://doi.org/10.32503/cendekia.v2i1.953

Srirejeki, K., Faturahman, A., Warsidi, W., Ulfah, P., \& Herwiyanti, E. (2020). Pemetaan Potensi Desa untuk Penguatan Badan Usaha Milik Desa dengan Pendekatan Asset Based Community-Driven Development. Warta LPM, 23(1). https://doi.org/10.23917/warta.v23i1.8974 
Sumerta, I. K., Redianingsih, N. K., Pranawa, I. M. B., \& Indahyani, D. N. T. (2020). Pengaruh Tingkat Penggunaan Media Sosial Dan Motivasi Terhadap Minat Berwirausaha Pada Mahasiswa Program Studi Manajeman Perguruan Tinggi Di Kota Denpasar. E-Jurnal Ekonomi Dan Bisnis Universitas Udayana. https://doi.org/10.24843/eeb.2020.v09.i07.p03

Sumerta, I. K., Widyagoca, I. G. P. A., \& Meryawan, I. W. (2019). Online consumer behavior on using social media on E-commerce, based on the AISAS model approach. Case study; Bukalapak, Tokopedia and Blili.com. International Journal of Advanced Trends in Computer Science and Engineering, 8(1.5 Special Issue). https://doi.org/10.30534/ijatcse/2019/4281.52019 